\title{
Factors Affecting Success in the Professional Entry Exam for Accountants in Brazil
}

\author{
Lúcia Lima Rodrigues ${ }^{\mathrm{a}}$, Carlos Pinho ${ }^{\mathrm{b}}$, Maria Clara Bugarimc, Russell Craig ${ }^{\mathrm{d}} \&$ Diego Machado $^{\mathrm{e}}$ \\ a GOVCOOP, School of Economics and Management, University of Minho, Gualtar, Portugal; \\ ${ }^{b}$ GOVCOOP, University of Aveiro, Aveiro, Portugal; 'Programa de Pós-graduação em Administração,

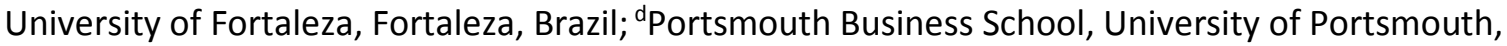

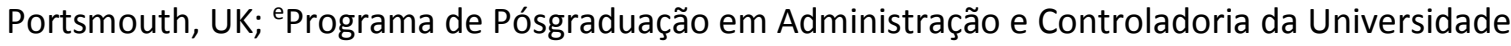 \\ Federal do Ceará, Fortaleza, Brazil
}

\begin{abstract}
This paper explores factors that have affected the success of candidates in the professional entry exam conducted by Brazil's Federal Council of Accounting. We analyse results of 18,948 candidates who sat for the exam in 2012, using a logistic regression model and the key indicators used by government to monitor the performance of Higher Education Institutions (HEIs) and the characteristics of candidates. We find that success is related positively to the quality of the HEIs from which candidates graduated and to a measure of student ability that is used widely in Brazil. We find also that males perform better than females and that younger candidates perform better than older candidates. The geographical region of Brazil within which candidates completed the exam was also significant. The insights provided will help public policy makers in Brazil, and the Brazilian accounting profession, to understand key factors associated with current low pass rates.
\end{abstract}

Keywords: Professional, entry, exam; Brazil; accounting. 


\section{Factors Affecting Success in the Professional Entry Exam for Accountants in Brazil}

\section{Introduction}

In July 1931, the Brazilian accounting profession was regulated for the first time. Henceforth, certification as an accountant required a diploma from an authorized institution, validated by the Superintendent of Commercial Education (Decree 20158, Section III). This regulation was prompted by the policy commitment of Brazil's corporatist government of President Vargas (1930-1945) to industrialise and attain economic self-sufficiency. Such policy created a need for a strong supply of well-trained accountants to help govern Brazil and to administer national and state tax systems (Rodrigues, Schmidt, Santos, \& Fonseca, 2011; Rodrigues, Schmidt, \& Santos, 2012).

In 1946, the professional practice of accountants in Brazil was regulated by the Federal Council of Accounting [CFC]; and by a Regional Accounting Council [CRC] in each state. This was known as the CFC/CRC system. All accountants were required to be registered in the state in which they practised. The CFC/CRC system has continued to control entry to the accounting profession. In 1999, a professional entry exam (Exame de Suficiência- Proficiency Exam) was introduced by the CFC in response to the proliferation of poor quality Higher Education Institutions [HEIs] in Brazil and the perceived quality of their graduates' preparedness for professional qualification. Hereafter, we refer to this exam as the CFC exam.

This paper investigates factors affecting the pass rate in the CFC exam. Although there have been many similar investigations of performance in professional entry exams in accounting in other countries, ${ }^{1}$ to the best of our knowledge, we are the first to explore such factors in Brazil. Previous studies of the CFC exam (all in Portuguese) are descriptive and/or merely present some basic statistical facts (Neto, 2009; Bugarim, Rodrigues, Pinho, \& Machado, 2014). Despite the increasing importance of accountants in Brazil (Rodrigues et al., 2011), little is known about the entry exam and the factors associated with candidate performance. This paper brings knowledge of accounting education in Brazil to non-Brazilian readers, and provides findings that will help in the development of higher education policies and regulation in Brazil. The importance of the Brazilian economy in the world context, and the need to improve its higher education and professional accounting system, make Brazil an ideal setting for this enquiry.

The Brazilian experience is important to a broader international audience for three major reasons. First, the condition of Brazil's economy and the quality of its infrastructure of professions, such as accounting, should be of strong concern globally. Brazil is one of the top 10 largest economies in the world by nominal Gross Domestic Product [GDP]. It is a member of the G20 and G8+5 international political groupings of major economies. Despite this growing economic and political prominence, little has been published in English language scholarly journals about the accounting profession in Brazil and its educational requirements. This is a matter we seek to address here.

Second, it is important to understand the factors that constrict the supply of accountants entering the accounting profession. Reasons for low pass rates in professional entry exams should be sought keenly by professional accounting bodies globally. The knowledge we provide here offers the prospect of helping to promote a stronger flow of accounting graduates to the profession, and of improving the quality of higher education in accounting in 
Brazil. Accounting programs in Brazil need to be scrutinised to understand whether the restructuring of curriculum necessitated by the adoption of International Financial Reporting Standards [IFRS] has improved accounting education (Freitas, 2016). Such understanding can be beneficial also to other (especially developing) countries which have adopted IFRS, or are seriously contemplating doing so.

Third, a well-developed understanding of candidates' performance in the CFC exam is important because a strong supply of well-trained, suitably credentialed accountants is critical if Brazil is to sustain economic development and maintain political stability. The insights offered here are intended to identify and ameliorate pass rate factors that are impeding the supply of accountants, and encourage actions that will enhance their supply (e.g., through public policy initiatives of government or directives to improve accounting education in Brazil). Additionally, more broadly, our findings will help to assess whether previously reported factors associated with professional entry exam performance in other countries are context-specific or can be generalized to other national settings.

Our principal finding is that the pass rate in CFC exam is influenced strongly by the rating of HEIs in which candidates completed the CFC exam. Another important finding is that the score in the ENADE exam [Exame Nacional de Desempenho dos Estudantes National Examination of Student Performance], undertaken by first year and final year students in accounting degrees, is strongly associated with pass rates. There is clear evidence that males perform better than females; that younger candidates perform better than older ones; and that candidates from the Southeast and Northeast regions of Brazil are almost two times more likely to pass the CFC entry exam than candidates from the North region. These results draw attention to probable inequalities in educational opportunity and educational infrastructure between regions.

We begin by outlining the Brazilian context before reviewing literature that has analysed factors influencing success in professional entry exams in accounting. Thereafter, we describe the research design, present and discuss results, enter conclusions, and propose avenues for future research.

\section{Brazilian Context}

Brazil is the largest economy in Latin America and is the fifth largest country in the world. Recently, Brazil has experienced a period of economic recession, caused mainly by problems of public policy (Reis, 2016). Brazil has high levels of income inequality, low human development indexes, and high illiteracy rates (Matos, 2017). The Federal Constitution and Law 9.394/1996 established guidelines and bases of national education which determine that the Federal Government, States, Federal District and municipalities, must manage their respective education systems. Each of these public education systems is responsible for its funds management and funding sources. The constitution reserves $25 \%$ of state budgets and $18 \%$ of federal taxes and municipal taxes for education. ${ }^{2}$

\subsection{Accounting Education}

The first degree in accounting in Brazil was conferred by the University of São Paulo in 1945 (Rodrigues et al., 2012). This precipitated rapid growth in offering accounting degrees throughout Brazil. In 2012, 893 HEIs offered a degree in accounting. Of these, only 103 were government funded. The proportion of non-government funded HEIs increased from $72 \%$ in 1991 to $88 \%$ in 2012. The percentage of enrolled female students increased from $44 \%$ in 1991 to $58 \%$ in 2012. Although an accounting degree was the third most popular choice of 
first year enrolments in HEIs in 2012, accounting was ranked only fifth in numbers of graduating students (MEC, 2012).

Figure 1 plots the very strong increase in Brazil in the number of accounting programs between 1991 and 2012.

Figure 1: Number of accounting degrees, 1991-2012 in Brazil

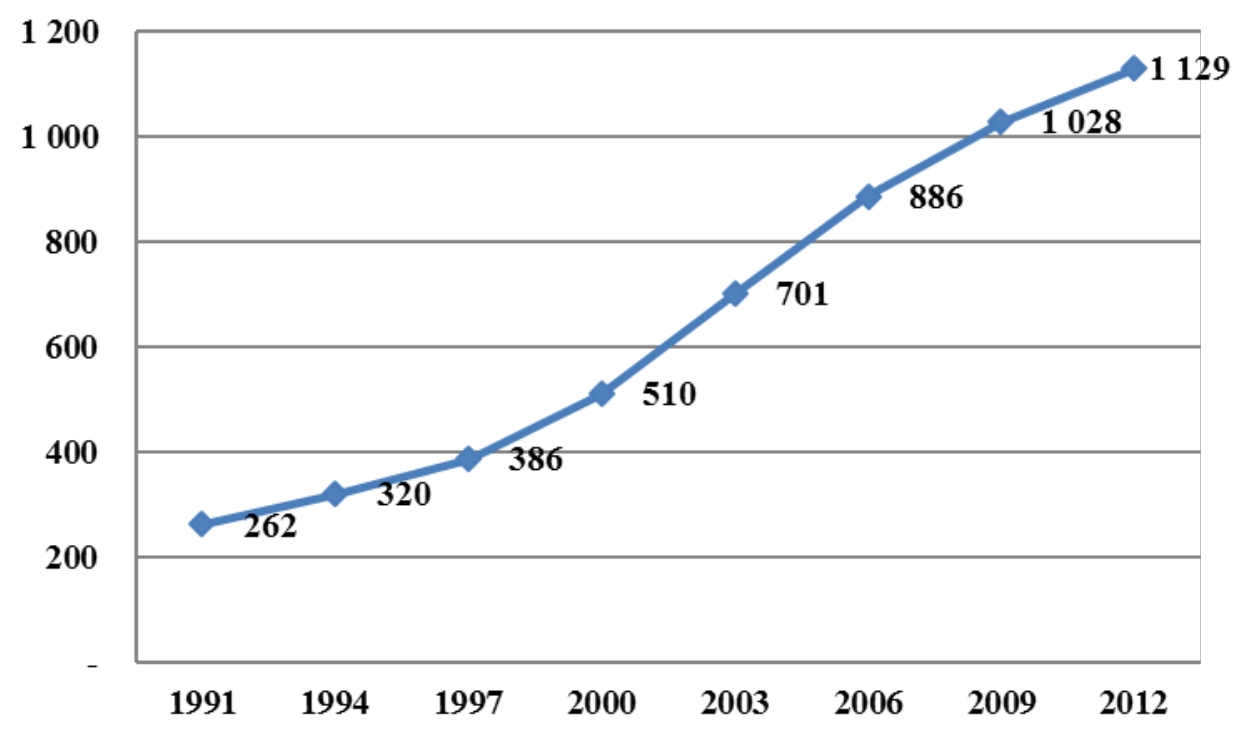

Source: MEC (2012).

The growth in accounting degree offerings, and the number of graduates, has been accompanied by concerns that the quality of their graduates' preparedness for professional qualification has been weakened by the proliferation of profit-oriented, non-government funded HEIs (Iudícibus \& Marion, 1986; Nossa, 1999a; 1999b). Such concerns prompted the CFC to believe that poor pass rates in the CFC exam were caused by the poor quality of many HEIs. This view was encouraged by findings that for-profit institutions in the US significantly underperformed not-for-profit institutions in the uniform certified public accountant [CPA] examinations (Hahn \& Fairchild, 2015).

Most private HEIs are of low quality (Iudícibus \& Marion, 1986; Freitas, 2016) and have low ratings. This is a concern for the Brazilian accounting profession. The quality of educational programs in HEIs has been strongly debated in Brazil, consistent with a global trend to engage in national assessments of HEIs (Freitas, 2016). Governmental agencies and external evaluation provided by organizations such as the European Association for Quality Assurance in Higher Education (ENQA) or the Association to Advance Collegiate Schools of Business (AACSB) are regarded as important mechanisms for assuring the quality of HEIs and their degree offerings. These organizations are helping educational institutions to improve their accounting programs (Freitas, 2016), and thus, help develop a stronger accounting profession. Nossa (1999a, 1999b) advanced three reasons for the low quality of accounting education in Brazil: the extraordinary expansion of the number of degrees; the lack of investment by HEIs; and the reduced number of master's and doctoral programs.

In 1961, graduate education was introduced by law 4024 (Rodrigues et al., 2012). The Federal Education Council (Conselho Federal de Educação - CFE Opinion 977), issued in 1965, distinguished between graduate studies which were Lato Sensu ${ }^{3}$ (practice-oriented) and those which were Stricto Sensu (research-based). The first Stricto Sensu programs in accounting were introduced in the 1970s. The pioneer master's and $\mathrm{PhD}$ programs were 
offered by the Faculty of Economics, Administration and Accounting of the University of São Paulo (Peleias, Silva, Segreti, \& Chiorotto, 2006), in 1970 and 1978, respectively. The creation of Stricto Sensu programs provided the necessary foundation for improvements in research and scientific production in accounting in Brazil.

Despite efforts to increase the number of holders of master's degrees and doctorates in accounting, the numbers are still very low. The National Association of Postgraduate Programs in Accounting Sciences reveals that, as of September 30, 2014, there were only 3,264 master's degree holders and 275 PhDs in accounting in Brazil.

The quality of HEIs is controlled by CAPES (Coordenação de Aperfeiçoamento de Pessoal de Nível Superior - Higher Education Personnel Training Coordination) and by the MEC (Ministério da Educação - Ministry of Education). The indicators they use to monitor the performance of HEIs are explained below.

\subsection{Evaluation Indicators for Higher Education Institutions}

Measurement of the quality of HEIs has developed from an unstable beginning at the end of the 1970s and beginning of the 1980s (Freitas, 2016). The Brazilian educational evaluation system has developed and improved since then, but has faced two primary difficulties: the lack of people with program evaluation expertise; and the instability of the political system and public policy (Freitas, 2016).

In the mid-1990s, the Brazilian government implemented an evaluation system for higher education. In 1995, Law 9131 established the ENC (Exame Nacional de Cursos - National Exam of Degrees). Thereafter, all graduating students in defined fields of knowledge (including accounting) were required to complete the ENC. In 2001, further laws were introduced to improve education. These included the Censo de Educação Superior (Census of Higher Education) and the Avaliação das Condições de Ensino (Evaluation of Teaching Conditions). They required MEC-appointed external commissioners or inspectors to visit HEIs.

Initially, the ENC was boycotted by students in many HEIs, but it soon became part of the culture of higher education in Brazil. The ENC grew from examining three areas of knowledge in 1995, to examining 26 in 2003. Nevertheless, the ENC was criticized strongly during Brazil's presidential election campaign of 2002. Shortly after President Luiz Lula da Silva took office in 2003, he proposed a new system called SINAES (Sistema Nacional de Avaliação da Educação Superior - National System of Evaluation of Higher Education, approved in April 2004, Law 10861). Under the SINAES system of assessing the quality of HEIs, the ENC was reformed to become the ENADE (Verhine, Dantas, \& Soares, 2006), explained below.

\subsubsection{ENADE}

The MEC uses ENADE to assess the performance of students against syllabus benchmarks; and to test their ability to apply knowledge in advanced practical settings (Pereira, 2012).

After public consultation, the MEC issued Opinion CNE/CES 289/2003. This elaborated on, and approved, National Curricular Guidelines (Diretrizes Curriculares Nacionais) for undergraduate degrees in accounting offered by HEIs. Santos and Afonso (2016) concluded that the level of cognitive knowledge of the area (defined in the Directrizes Curriculares Nacionais) was appropriate; but that technical deficiencies became apparent in the construction of questions in the 2002 and 2003 ENC exams, and to a lesser extent in the 2006 ENADE exam. 
ENADE uses the overall score achieved by students to evaluate the quality of their degree (Barreyro, 2008). ENADE is conducted each year for a selection of degrees. However, it is only conducted every three years for any specific degree (Ristoff \& Giolo, 2006). The accounting degree was last subject to ENADE in 2015.

This study uses results for the penultimate ENADE for accounting, conducted in 2012. In that year, 932 accounting degrees and 47,299 students were evaluated (MEC, 2012). Each ENADE is applied to a sample of students from the first year and the last year (the fifth in Brazil) in each degree. ${ }^{4}$ Such entry and exit sampling enables assessments to be made of the contribution of the degree to the educational development of students (Fernandes, Pazello, Leitão, \& Moriconi, 2009).

ENADE consists of a general knowledge exam and a discipline-specific exam. ${ }^{5}$ The general knowledge exam assesses topics such as social diversity, biodiversity, globalization, geography, economics, public policy, interpersonal relations, digital awareness, and citizenship (Schwartzman, 2008). The discipline-specific exam aims to determine what students have learned during their degree by comparing the knowledge of beginning students with that of students who are about to graduate (Brito, 2008). ENADE also assesses the professional skills possessed by final year students. Additionally, ENADE includes three questionnaires. Two are completed by students. They provide their perceptions of the exam and socio-economic information about themselves. The other questionnaire is completed by program administrators (Freitas, 2016).

The resulting ENADE score (0.0 to 5.0) is allocated to a grade range (from 1 to 5 ) in accord with the following scale:

\begin{tabular}{|l|c|c|}
\hline Continuous ENADE score & Rating & $\begin{array}{c}\text { MEC } \\
\text { Assessment }\end{array}$ \\
\hline $0.00-0.94$ & 1 & Very poor \\
\hline $0.95-1.94$ & 2 & Poor \\
\hline $1.95-2.94$ & 3 & Sufficient \\
\hline $2.95-3.94$ & 4 & Good \\
\hline $3.95-5.00$ & 5 & Very good \\
\hline
\end{tabular}

A rating of 5 means "very good" performance from students and HEIs. A rating of 1 is deemed "poor." A rating of 3 is regarded as "sufficient." In 2012, 30\% of accounting degree programs received an ENADE rating of 1 or 2, and 46\% received a rating of 3 (MEC, 2012). This was an unsatisfactory result because only $24 \%$ of programs were rated as "good" or "very good" (ratings of 4 and 5). Such a result is not surprising in view of the poor performance of candidates in various offerings of the CFC's professional entry exam between 2000 and 2004, in 2011, and in 2012 (Bugarim et al., 2014).

Apart from ENADE, the MEC relies upon several other indicators of the quality of degrees and HEIs, discussed below. These indicators have had a positive impact on the quality of higher education in Brazil (Marchelli, 2007).

\subsubsection{CPC (Conceito Preliminar de Curso) - Preliminary degree assessment}

The principal objective of the CPC is to serve as a preliminary indicator of degree quality. The CPC identifies HEIs whose degrees warrant on-site review: that is, those whose 
CPC is rated 1 or 2 (Fernandes et al., 2009; Peixoto, 2011). When an on-site visit is requested and conducted, a Conceito de Curso [CC] (or final degree rating) is assessed by on-site inspectors. If the CC rating departs from the CPC rating, strong justification is required.

The CPC was first used in 2008 to provide a preliminary rating (from 1 to 5) of a degree (Castanheira, Masson, \& Miranda, 2010). According to MEC criteria, a rating of 5 indicates a degree is exemplary; a 4 indicates high quality; a 3 indicates a degree meets minimum conditions; and ratings of 1 or 2 indicate that a degree needs improvement (Vasconcelos, 2010). A rating of 3 is the minimum acceptable grade for degree accreditation (Art. 32, Ordinance 2051, republished in 2010).

The CPC rating is based on students' performance in the ENADE exam and on their questionnaire-based evaluations of the infrastructure, educational teaching resources, and quality of faculty in their HEIs. Thus, the preliminary CPC rating is based on information collected through ENADE, without on-site inspection by assessors. If a degree of a higher education institution attains a rating of 3,4 or 5 , the institution can waive the on-site inspection. If so, the CPC rating is the degree rating (or CC).

When HEIs do not agree with their CPC rating, they can ask for a CC (degree rating). This latter rating is assigned by inspectors, based on their on-site assessment of a degree (INEP 2008). The CC rating considers specific features of degrees that cannot be assessed from the questionnaire responses of students in the CPC evaluation (Fernandes et al., 2009). Because of the large number of degrees offered throughout Brazil, it is infeasible to conduct on-site reviews every three years in some areas of knowledge. Thus, a CC rating can only be obtained on request.

\subsubsection{IGC (Índice Geral de Cursos): General rating of all degrees of a HEI}

The IGC was created by Decree 12, 2008 and is published annually (Brito, 2008). It assesses the quality of all degrees offered by a higher education institution (Bittencourt, Casartelli, \& Rodrigues, 2009). The IGC is an average of the CPC rating of all individual degrees offered by an institution, as shown below:

$\mathrm{IGC}=\{[\mathrm{PGrad} * \mathrm{G}]+[$ PMaster $*(\mathrm{M}+5) / 2]+[\mathrm{PPHD} *(\mathrm{D}+10) / 3]\} * 100$

where

$\mathrm{G}$ = weighted average of the CPCs of the institution in undergraduate courses (weighting in accord with the number of students enrolled in each course).

$\mathrm{M}$ = weighted average of CAPES ratings in graduate programs at master's level (weighted in accord with the number students enrolled in master's degrees).

$\mathrm{D}$ = weighted average of CAPES ratings in graduate programs, at $\mathrm{PhD}$ level (weighted in accord with the number of students enrolled in PhDs).

PGrad, PMast and PPHD = the respective percentage of undergraduate, master's and doctoral degree students.

The resulting IGC ranges from 0 to 500 points. Due to the methodology used by MEC/INEP, the extremity values (very poor and very good) are less probable. 


\begin{tabular}{|c|l|l|}
\hline Continuous IGC score & Rating & MEC Assessment \\
\hline $00-94$ & 1 & Very poor \\
\hline $95-194$ & 2 & Poor \\
\hline $195-294$ & 3 & Sufficient \\
\hline $295-394$ & 4 & Good \\
\hline $395-500$ & 5 & Very good \\
\hline
\end{tabular}

As with the CPC, HEIs can request a Conceito Institucional (CI) rating. Unlike the IGC (whose score is calculated by only considering the $\mathrm{CPC}$ ), the $\mathrm{CI}$ rating requires on-site visits.

\subsection{The CFC/CRC system and the CFC exam}

In September 1945, by decree 7988, Vargas established the first university degree in accounting and actuarial science (Rodrigues et al., 2012). This prompted Brazilian accountants to seek regulation of the accounting profession. In May 27, 1946, decree 9295 created the Federal Council of Accounting (CFC) and Regional Councils of Accounting (CRC) in every state (Rodrigues et al., 2012). They were made responsible for enforcing legal requirements for the accounting profession. These councils were formed consistent with the corporatist government policy of creating official agencies to regulate and supervise the practice of professions so that there could only be one representative institution per jurisdiction (Rodrigues et al., 2011; 2012). Decree 9295 also established the required credentials professional accountants should have: accountants (contadores) should hold a university accounting degree; accounting technicians (técnicos de contabilidade) should have a commercial high school degree; bookkeepers (guarda-livros) should have practical experience (Rodrigues et al., 2012).

In 1958, in a period of intense change arising from "the targets plan" of Juscelino Kubitchek, Law 3384 established a new profile of professional accountants: accountants (contadores) and accounting technicians (técnicos de contabilidade). The category for bookkeepers ceased to exist but was subsumed in the category of accounting technicians.

In 1999, CFC Resolution 853 established an entry exam for accounting professionals (CFC Exam). The intent was to protect the quality of the accounting services provided by CFC/CRC members. From 1999, accountants could be registered only if they had passed the CFC exam. This requirement was intended to protect the quality of accounting services provided by CFC/CRC members. The exam was a way of controlling the perceived deficiencies in accounting education, including those highlighted by Iudícibus and Marion (1986). Coelho (1999) asserted that the CFC exam would lead to gradual improvements in accounting teaching (see also Madeira, Mendonça, \& Abreu, 2003).

The CFC exam was suspended in 2005 because of conflict with the Constitutional Principle (Article 5) that any citizen should be free to carry on any work, trade or profession, if legally-prescribed professional qualifications were met. Because the CFC exam had not been established by law, but by a CFC resolution, it was deemed unconstitutional. ${ }^{6}$ The situation changed in 2010 when Brazil adopted IFRS. This prompted re-institution of the CFC exam (Law 12249; CFC Resolution 1301) and a ruling that, from 2015 onwards, a bachelor's degree would be required for registration as an accountant. Specifically, Article 12 of Law 12249 stated that candidates "may exercise the profession only after completing a bachelor's degree in accounting that is recognized by the Ministry of Education, passing the CFC exam, and being registered by a Regional Council of Accounting.” 
The CFC exam resumed in 2010 and is offered twice yearly. Candidates are required to attain a mark of at least 50\% to pass. In 2012, the pass rate in the CFC's professional entry exam declined to 24\%. This compares unfavourably with the indicative pass rates achieved by candidates in the various component exams for professional entry conducted by leading international professional accounting bodies. For example, the Association of Certified Chartered Accountants (7 papers, pass rates from 32\% to 50\%, September 2015: http://www.accaglobal.com/ng/en/student/exam-support-resources/professional-exams-studyresources/pass-rates-professional-exams.html); Institute of Chartered Accountants in England and Wales (8 papers, pass rates from 78\% to 92\%, September 2016, http://examresults.icaew.com/home/Stats/); and Chartered Institute of Management Accountants (9 papers, pass rates from 63\% to 92\%, January and September 2015, http://www.cimaglobal.com/Press/Press-releases/2016/CIMA-releases-latest-tranche-ofexam-pass-rates/).

Using CFC population data, in Figure 2 we present the pass rates in the 14 CFC exams. The highest pass rate was in the first exam in 2000 (83.52\%), and the worst was the CFC exam that is analysed in this paper (23.78\%).

Figure 2: Evolution in the results in the CFC exam from 2000 until 2012

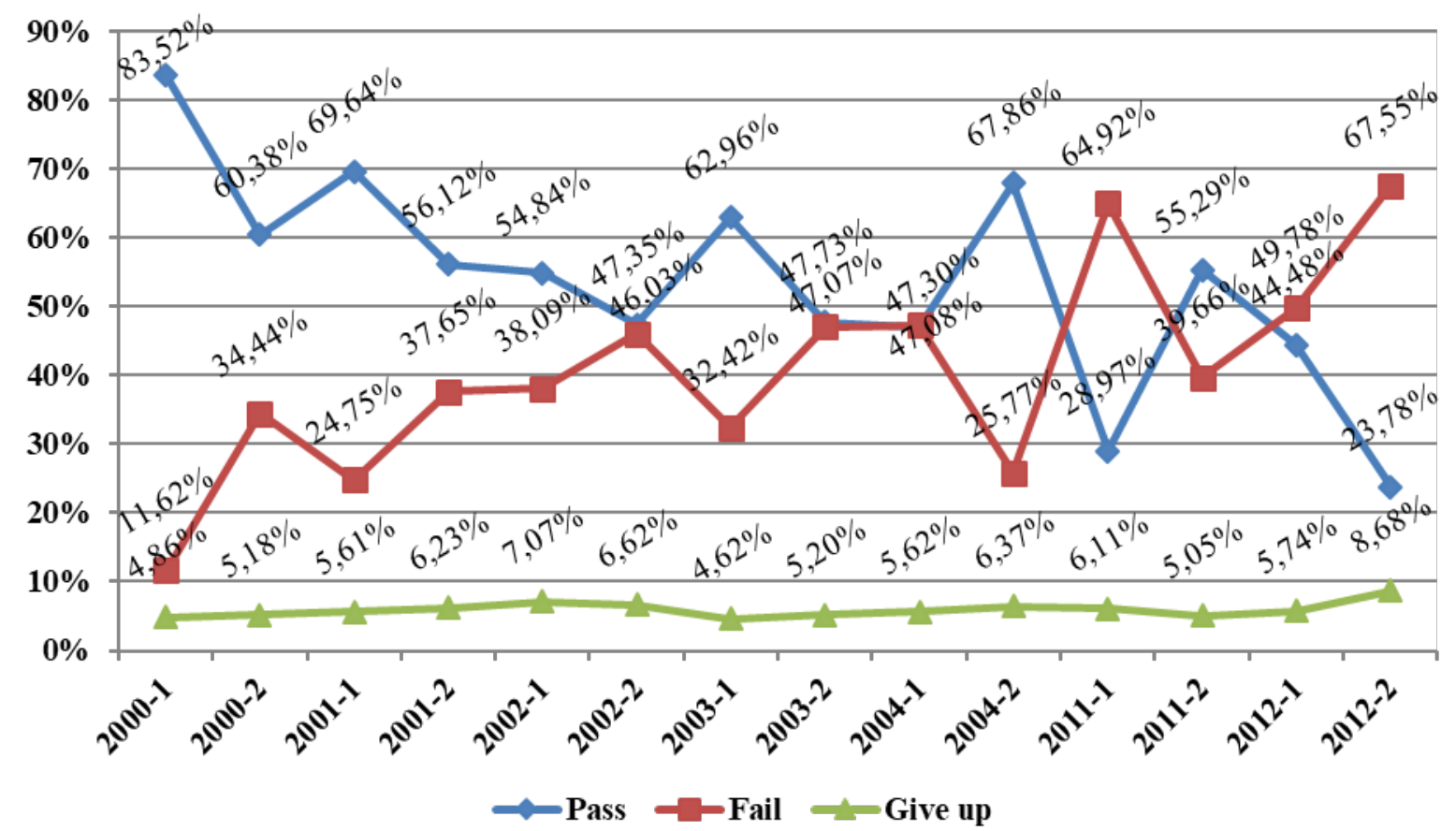

The CFC exam is of 4 hours duration and is composed of 50 multiple choice questions worth one point each. The following topics are covered:
a) General Accounting
b) Cost Accounting
c) Accounting Applied to the Public Sector
d) Management Accounting
e) Internal Control
f) Notions of Law and Applied Law
g) Financial Mathematics and Statistics
h) Accounting Theory
i) Legislation and Professional Ethics 
j) Accounting Principles and Brazilian Accounting Standards

k) Auditing

l) Forensic Accounting

m) Applied Portuguese.

Law 12249 also directed that accounting technicians would be registered only until 1 June 2015. After that date, only candidates holding a bachelor's degree in accounting would be eligible for registration as an accountant (Article 12, No. 2). This requirement is common in many European countries, such as Portugal, and also in the USA. As will be seen in the literature review, in many states of the USA, the CPA exam requires 150 credit hours. Undergraduate degrees carry 120 credit hours. This means students will have to achieve 30 hours of graduate level coursework. Some states also require that a CPA candidate have two years of work experience in accounting or tax preparation.

\section{Literature Review and Development of Hypotheses}

Boone et al. (2006) investigated average pass rates in 520 US accounting programs that had provided 43,711 first-time candidates for CPA exams in 1998 and 1999. They found higher average pass rates were achieved by graduates from more selective schools, holders of advanced degrees (see also Titard \& Russell, 1989), and graduates of schools located in jurisdictions with a 150 credit-hour degree requirement. The effect of the latter requirement to become a CPA in the US has been analysed extensively (Allen \& Woodland, 2006; 2012; Gramling \& Rosman, 2009; 2013; Haen et al., 2014). The balance of accumulated evidence shows that the 150 credit-hour requirement is not a critical factor in improving student success in the CPA exam.

Several characteristics associated with good performance in the CPA exam in the US include whether a candidate has a high college grade point average [GPA]; a high Scholastic Assessment Test [SAT] score; a higher degree; and a degree from an institution accredited by the AACSB (Marts, Baker, \& Garris, 1988; Grant et al., 2002; Barilla et al., 2008; Morgan, 2015). The latter relationship has been explained as reflecting the ability of AACSBaccredited institutions to attract better students (Howell \& Heshizer, 2006). Candidates with bachelor's degrees from AACSB accounting-accredited schools have been found to outperform candidates with bachelor's degrees from AACSB business-accredited only schools and unaccredited schools (Miller \& Nouri 2015). Other influential factors are the age of candidate; whether a candidate takes part in an in-class CPA review program; and whether a candidate takes advantage of increased hours of independent study (Dunn \& Hall, 1984; Titard \& Russell, 1989; Howell \& Heshizer, 2008). The average delay after graduation before taking the CPA exam has been found to have a significant negative effect on CPA exam pass rates (Morgan, 2015).

We draw on this literature to develop hypotheses related to HEIs; and then hypotheses related to candidate characteristics.

\subsection{Hypotheses related to HEIs}

In line with the evidence reported above, we propose that:

H1: The pass rate in the CFC exam is related positively to the quality of a higher education institution. 
Since most HEIs do not have a CC rating, we use the IGC rating as a proxy measure of the quality of each higher education institution.

We also hypothesize that:

H2: The pass rate in the CFC exam is related positively to the quality of the bachelor's degree in accounting.

Since most HEIs do not have a CC rating, we use the CPC as a proxy to measure the quality of the bachelor's degree in accounting.

Based on evidence provided by Boone et al. (2006), we hypothesise that pass rates are related positively to the research productivity of faculty members. Similarly, influenced by Bline, Perreault, and Zeng (2015), we hypothesise that faculty research and teaching specializations are related positively to performance in the CFC exam. As a proxy for research productivity, we use the percentage of faculty holding a master's degree in accounting (MAST). They will be more likely than non-holders of such degrees to conduct research and to publish papers in scientific journals. We do not use the percentage of teachers holding a PhD degree because other than for the University of São Paulo, ${ }^{7}$ the number of faculty members holding a $\mathrm{PhD}$ is very small. We hypothesize that:

H3: The pass rate in the CFC exam is related positively to the percentage of faculty holding a master's degree in accounting.

\subsection{Hypotheses related to candidate characteristics}

Several studies have concluded that the intellectual capacity of students is correlated positively with pass rates (e.g., Colbert \& Murray 1998; Grant et al., 2002) and that "past academic performance is significantly related to future performance, i.e., grades predict other grades" (Eskew \& Faley, 1988, p.138). Indeed, Howell and Heshizer (2008) reported that almost two-thirds of CPAs they surveyed who had passed the CPA exam on the first or second attempt, had significantly higher GPA and SAT scores.

We used the ENADE score to measure the ability of individual candidates who attempted the CFC exam. ${ }^{8}$ This prompted us to explore the following hypothesis:

H4: The pass rate in the CFC exam is related positively to the score candidates obtained in the ENADE.

Santos (2012) used data from ENC in 2002 and 2003, and ENADE in 2006, to conclude that younger students performed better in undergraduate accounting programs than older students. Similarly, Diaz (2007) found that younger students in undergraduate management, law and civil engineering performed better in ENC 2000 than older students.

A study of professional entry related examination success of information systems analysts by Segall et al. (2007) concluded that age had a slight effect on exam success due to the greater work experience of older candidates. However, Howell and Heshizer (2006) found no significant relationship between passing the CPA exam and age. Indeed, Roos (2009) found that younger candidates who attended part-time tuition classes in South Africa were more successful in professional qualification examinations of the Chartered Institute of Management Accountants (CIMA). We hypothesise tentatively, and non-directionally, that:

$\mathrm{H} 5$ : The pass rate in the CFC exam is related to the age of candidates.

Females comprise the majority of accounting students in Brazil (MEC, 2012). Santos (2012) concluded that female accounting students perform worse than males in the ENC and ENADE exam. Similarly, Diaz (2007) found that female students in management, law and 
civil engineering, performed worse than males. Silva, Vendremini, and Lopes (2010) concluded that males achieved a significantly higher mean performance than women in the general and specific parts of the ENADE exam in the undergraduate programs in mathematics, letters, biology, history, geography and philosophy. Roos (2009) found that females performed better than males in the professional qualification examinations of the Chartered Institute of Management Accountants (CIMA). However, Bagamery et al. (2005) found that males performed better on the Educational Testing Service Major Field Exam in Business. Segall et al. (2007) did not find that the gender of candidates influences scores in the examination for information systems analysts. Thus, our hypothesis is non-directional:

H6: The pass rate in the CFC exam is related to gender.

Blanden, Gregg, and Macmillan (2007) reported an association between economic wellbeing and educational attainment. If such a relationship exists in the CFC exam results, it will highlight the need to improve educational resources in poorer regions. In the absence of information on each candidate's economic status, we analyse results according to the regions in which the candidate completed the CFC exam.

Brazil is divided into five regions: Central-west (including Brasilia, the national capital), Northeast (including the cities of Salvador, Fortaleza and Recife), North (Manaus, Belém), Southeast (São Paulo, Rio de Janeiro, Belo Horizonte) and South (Curitiba, Porto Alegre). The Instituto Brasileiro de Geografia e Estatística (IBGE) (Brazilian Institute of Geography and Statistics) reported that the GDP per capita in each region (in reais and in order of affluence) was 34,790 (Southeast), 32,322 (Central-west), 30,496 (South) 17,213 (North), 12,955 (Northeast). ${ }^{9}$ Bugarim et al. (2014) analysed results of the 14 CFC exams administered up to, and including, 2012. They reported that the South and Northeast regions had higher average rates of success (58\% and 57\% respectively) than the Southeast (54\%), Central-west (46\%) and North (44\%). Freitas (2016) and Diaz (2007) concluded that candidates from undergraduate accounting programs from the northern, central-west and northeastern achieved lower grades than HEIs from the southeast. Based on this previous evidence we hypothesize that:

H7: The pass rate in the CFC exam is related to the region of Brazil where the student completed the exam.

\section{Research Design}

\subsection{Sample Data}

The CFC in Brasília provided results data for the CFC exam conducted in the second semester of 2012, attempted by 31,999 candidates. From the MEC database we obtained the higher education institution rating (IGC), the rating for the bachelor's degree in accounting (CPC), number of staff holding master's degrees in accounting (MAST), and ENADE score. We accessed information on each candidate's age, gender and higher education institution from the CFC database. Because of 9 missing values in the CFC database, the sample was reduced to 18,957 candidates. After considering data from MEC, and noting that the variable MAST had 9 missing values, the final sample was reduced to the results for 18,948 candidates.

\subsection{Dependent and Independent Variables}


We used logistic regression to study the determinants of pass rates in the CFC exam. The dependent variable, CFC exam pass rate, is a dummy variable which classifies candidates as passed (1) or failed (0). ${ }^{10}$

The independent variables are:

IGC: rating of the higher education institution (continuous variable ranging from 0.00 to 5.00);

CPC: rating of the bachelor's degree in accounting (continuous variable ranging from 0.00 to 5.00 );

MAST: percentage of faculty holding a master's degree accounting (continuous variable ranging from 0.00 to 1.00$)^{11}$;

ENADE: rating of accounting students' exam (continuous variable ranging from 0.00 to 5.00);

GEN: dummy variable with 1 representing male, and 0 female;

AGE: a continuous variable indicating a candidate's age;

REG: a classificatory variable indicating the region from where the candidate completed the CFC exam: REG1 = North; REG2 = Northeast; REG3 = Southeast; REG4 = South; REG5 = Central-West.

\section{Results}

\subsection{Descriptive Statistics}

Table 1 reports descriptive statistics for the dependent and independent variables. The mean value of the IGC (2.409) and CPC (2.288) were below the minimum desired (3.0). The mean percentage of teachers holding a master's degree in accounting was 54\%. Some HEIs had no teachers with such degree. The mean value of ENADE scores was 2.3, reflecting poor performance by candidates. The average age of candidates was about 29 years, and $57 \%$ were female. About $32 \%$ of males passed the exam, but only about $23 \%$ of females did so. The best results in the CFC exam were achieved in regions 2, 3 and 4. The average pass rate in these three regions together was about 30\%. The pass rate in region 1 was $13 \%$. In region 5 it was $20 \%$. 
Table 1: Descriptive statistics

Panel A: Dependent and independent continuous variables

\begin{tabular}{|l|c|c|c|c|c|c|c|c|}
\hline Variables & & Success & Failure & Total & Mean & $\begin{array}{c}\text { Std. } \\
\text { Dev. }\end{array}$ & Min & Max \\
\hline Dependent variable: CFC Exam pass rate & & & & & & \\
\hline Freq. & & 5,061 & 13,887 & 18,948 & & & & \\
\hline Percent & 26.71 & 73.29 & 100 & & & & \\
\hline Independent Variables: & & & & & & & \\
\hline IGC & & & & & 2.409 & 0.532 & 1.14 & 4.363 \\
\hline CPC & & & & 2.288 & 0.649 & 0.758 & 4.574 \\
\hline MAST & & & & & 0.540 & 0.219 & 0 & 1 \\
\hline ENADE & & & & & 2.301 & 0.756 & 0.086 & 4.677 \\
\hline AGE & & & & & 29.167 & 7.59 & 18 & 79 \\
\hline
\end{tabular}

Panel B: Independent categorical and classificatory variables

\begin{tabular}{|l|r|r|r|r|r|}
\hline \multicolumn{2}{|l|}{ GEN [categorical variable] } & \multicolumn{1}{l|}{ Success } & Failure & \multicolumn{1}{c|}{ Total } & $\begin{array}{c}\text { Percentage } \\
\text { pass rate }\end{array}$ \\
\hline \multicolumn{1}{|c|}{ Male (=1) } & 2,569 & 5,513 & 8,082 & 31.79 \\
\hline Female (=0) & & 2,492 & 8,374 & 10,866 & 22.93 \\
\hline \multicolumn{1}{|c|}{ Male/Female } & & & 0.43 & \\
\hline $\begin{array}{l}\text { Region } \\
\text { [classificatory } \\
\text { variable] }\end{array}$ & & & & \\
\hline REG1 & & & & \\
\hline REG2 & & 912 & 2,431 & 3,343 & 27.28 \\
\hline REG3 & & 2,323 & 5,579 & 7,902 & 29.39 \\
\hline REG4 & & 1,156 & 2,542 & 3,698 & 31.26 \\
\hline REG5 & & 447 & 1,777 & 2,224 & 20.10 \\
\hline
\end{tabular}

IGC: General rating of all degrees offered by a higher education institution; CPC: Preliminary degree assessment; MAST: percentage of faculty holding a master's degree; ENADE: National Examination of Student Performance; AGE: candidate age; GEN: Male $(=1)$; Female $(=0)$. Region classifies candidates according to the region where they completed the exam: REG1= North; REG2= Northeast; REG3= Southeast; REG4=South; REG5= Central-West.

Table 2 shows that better CFC and IGC ratings were achieved in regions 4, 3, and 2, respectively. The results for the South and Southeast regions were expected since they are the richest regions in Brazil (Freitas, 2016). Although region 2 is the poorest region, it has HEIs with higher CPC and IGC scores than regions 1 and 5. This suggests that the investment in education in region 2 is more effective in terms of accounting education outcomes. 
Table 2: CPC and IGC per region

\begin{tabular}{|l|l|l|l|l|l|}
\hline $\begin{array}{l}\text { Variable } \\
\text { Region }\end{array}$ & Obs. & Mean & STD & Min & Max \\
\hline $\boldsymbol{R E G 1}$ & & & & & \\
\hline CPC & 1,781 & 1.895 & 0.596 & 0.841 & 3.063 \\
\hline IGC & 1,781 & 2.028 & 0.469 & 1.328 & 2.964 \\
\hline $\boldsymbol{R E G 2}$ & & & & & \\
\hline CPC & 3,343 & 2.105 & 0.591 & 0.772 & 3.577 \\
\hline IGC & 3,343 & 2.351 & 0.573 & 1.184 & 3.660 \\
\hline $\boldsymbol{R E G 3}$ & & & & & \\
\hline CPC & 7,902 & 2.371 & 0.548 & 0.758 & 4.284 \\
\hline IGC & 7,902 & 2.444 & 0.460 & 1.178 & 4.363 \\
\hline $\boldsymbol{R E G 4}$ & & & & & \\
\hline CPC & 3,698 & 2.657 & 0.589 & 1.185 & 4.132 \\
\hline IGC & 3,698 & 2.663 & 0.533 & 1.160 & 4.283 \\
\hline REG5 & & & & & \\
\hline CPC & 2,224 & 1.970 & 0.781 & 0.845 & 4.574 \\
\hline IGC & 2,224 & 2.257 & 0.517 & 1.141 & 3.881 \\
\hline
\end{tabular}

IGC: General rating of all degrees offered by a higher education institution; CPC: Preliminary degree assessment; REG1 $=$ North; REG2 $=$ Northeast; REG3 $=$ Southeast; REG4 $=$ South; REG5 $=$ Central West.

Table 3 reveals that female candidates are younger than male candidates since the percentage of females in the range 18 to 25 (59.96\%) is higher than the mean (57.35\%). In the older group (>50 years) the percentage of females is only $41.18 \%$. This suggests that the Brazilian accounting profession is attracting mainly young female candidates, but is not retaining them well. 
Table 3: Gender by age

\begin{tabular}{|r|r|r|r|r|}
\hline Variables & Males & Females & Total & Females (\%) \\
\hline Freq. & 8,082 & 10,866 & 18,948 & \\
\hline Percent & 42.65 & 57.35 & 100 & AGE \\
\hline \multicolumn{5}{|l|}{} \\
\hline Group by age & & & & 59.96 \\
\cline { 2 - 6 }$[18-25]$ & 3,100 & 4,643 & 7,743 & 56.71 \\
\cline { 3 - 6 }$[26-35]$ & 3,448 & 4,516 & 7,964 & 54.25 \\
\cline { 3 - 6 }$[36-50]$ & 1,304 & 1,546 & 2,850 & 41.18 \\
\cline { 2 - 6 } & 230 & 161 & 391 & \\
{$[51-79]$} & &
\end{tabular}

Our analysis of the distribution of candidates in each region by age, shows that there are two main differences when compared with the distribution of candidates in the country: in region 1 , candidates are older; while in region 4, candidates are younger than the mean for Brazil, especially when we consider candidates less than 25 years old (28\% for region 1 and $48 \%$ in region 4). Regarding gender per region, as the bivariate analysis presented in the next section suggests, there is no statistical difference between regions. ${ }^{12}$

\subsection{Bivariate analysis}

We analysed correlations among independent variables. The magnitude of the pair-wise correlation coefficients reported in Table 4 indicates that multicollinearity is minimal, except for CPC and IGC (where the correlation was 83.4\%) (Gujarati, 1995).

Table 4: Correlation coefficients

\begin{tabular}{|c|c|c|c|c|c|c|c|c|}
\hline & $\begin{array}{l}\text { CFC exam } \\
\text { pass rate }\end{array}$ & IGC & CPC & MAST & ENADE & GENDER & AGE & REG \\
\hline CFC exam pass rate & 1 & & & & & & & \\
\hline IGC & $0.231 * * *$ & 1 & & & & & & \\
\hline $\mathrm{CPC}$ & $0.200 * * *$ & $0.834 * * *$ & 1 & & & & & \\
\hline MAST & $0.135 * * *$ & $0,559 * * *$ & $0.607 * * *$ & 1 & & & & \\
\hline ENADE & $0.157 * * *$ & $0.457 * * *$ & $0.449 * * *$ & $0.168 * * *$ & 1 & & & \\
\hline GENDER & $0.099 * * *$ & -0.004 & -0.004 & $-0.026 * * *$ & $-0.029 * * *$ & 1 & & \\
\hline AGE & $-0.082^{* * *}$ & $-0.080^{* * *}$ & $-0.038 * * *$ & $0.015^{* *}$ & $-0.137 * * *$ & $0.062 * * *$ & 1 & \\
\hline REG & $0.039 * * *$ & $0.163^{* * *}$ & $0.144^{* * *}$ & $0.013 *$ & $0.192 * * *$ & -0.007 & $-0.108 * * *$ & 1 \\
\hline
\end{tabular}

* significant at $10 \%$; ** significant at $5 \%$; *** significant at $1 \%$.

IGC: General rating of all degrees offered by a higher education institution; CPC: Preliminary degree assessment; MAST: percentage of faculty holding a master's degree; ENADE: National Examination of student performance; GEN: Male (=1); Female (=0); AGE: candidate age; Region (REG) is a classificatory variable that classifies candidates according to the region they completed the exam: REG1= North; REG2= Northeast; REG3= Southeast; REG4=South; REG5= Central-West.

The higher the IGC, CPC, MAST and ENADE the more likely a candidate is to pass the CFC exam. Older candidates, and female candidates are less likely to pass. This accords with 
results for Brazilian accounting students reported by Santos (2012) in the 2006 ENADE exam. Bivariate analysis permits us also to conclude that age is correlated negatively with CFC, IGC, CPC and ENADE. We have compared CPC and IGC with age. CPC and IGC average values decrease with age. However, this decrease is not statistically different. This tendency suggests that older candidates were more likely to have studied in low-rated HEIs. The positive correlation between age and gender means that older candidates are mainly male, as Table 3 reveals.

\subsection{Logistic regression analysis}

The dependent variable is a dummy variable, coded 1 for a pass candidate, and 0 for a fail candidate. We analyse three models. Model 1 includes all variables except REG variables. Model 2 includes all variables. Model 3 includes all variables except CPC (to reduce eventual multicollinearity problems). The variables were divided into three groups: HEI-related variables (IGC, CPC, MAST); candidate-related variables (ENADE, AGE, GEN); and region-related variables (dummy variable for regions). Thus:

\section{Model 1:}

CFC exam result $=\beta 0+\beta 1 \mathrm{IGC}+\beta 2 \mathrm{CPC}+\beta 3 \mathrm{MAST}+\beta 4 \mathrm{ENADE}+\beta 5 \mathrm{AGE}+\beta 6 \mathrm{GEN}+\varepsilon$

\section{Model 2:}

CFC exam result $=\beta 0+\beta 1 \mathrm{IGC}+\beta 2 \mathrm{CPC}+\beta 3$ MAST $+\beta 4$ ENADE $+\beta 5$ AGE $+\beta 6$ GEN +

Model 3:

$$
\beta 7 \text { REGION }+\varepsilon
$$

CFC exam result $=\beta 0+\beta 1 \mathrm{IGC}+\beta 2 \mathrm{MAST}+\beta 3 \mathrm{ENADE}+\beta 4 \mathrm{AGE}+\beta 5 \mathrm{GEN}+\beta 6 \mathrm{REGION}$ $+\varepsilon$

Model 3:

$\mathrm{CFC}$ exam result $=\beta 0+\beta 1 \mathrm{CPC}+\beta 2 \mathrm{MAST}+\beta 3 \mathrm{ENADE}+\beta 4 \mathrm{AGE}+\beta 5 \mathrm{GEN}+\beta 6 \mathrm{REGION}$ $+\varepsilon$

Table 5 shows that all models are significant (1\% level) with an explanatory power indicating the likelihood of one observation being correctly classified by the models is about 75\%. Panel B of Table 5 strongly confirms the appropriateness of Models 3 and 4. 
Table 5: Logistic regression models

\begin{tabular}{|c|c|c|c|c|c|c|c|c|}
\hline Panel A: Coefficients: & Model 1 & & Model 2 & & Model 3 & \multicolumn{3}{|c|}{ Model 4} \\
\hline \multicolumn{9}{|c|}{ Variables related to HEIs: } \\
\hline \multirow[t]{2}{*}{ IGC } & 0.766 & $* * *$ & 0.742 & $* * *$ & 0.760 & $* * *$ & - & \\
\hline & $(0.060)$ & & $(0.061)$ & & $(0.042)$ & & - & \\
\hline \multirow[t]{2}{*}{$\mathrm{CPC}$} & 0.022 & & 0.021 & & - & & 0.468 & $* * *$ \\
\hline & $(0.050)$ & & $(0.052)$ & & & & $(0.037)$ & \\
\hline \multirow[t]{2}{*}{ MAST } & 0.297 & $* * *$ & 0.197 & $* *$ & 0.209 & $* *$ & 0.414 & $* *$ \\
\hline & $(0.100)$ & & $(0.101)$ & & $(0.098)$ & & $(0.100)$ & \\
\hline \multirow[t]{2}{*}{ ENADE } & 0.182 & $* * *$ & 0.191 & $* * *$ & 0.192 & $* * *$ & 0.252 & $* * *$ \\
\hline & $(0.026)$ & & $(0.026)$ & & $(0.026)$ & & $(0.026)$ & \\
\hline \multirow[t]{2}{*}{ AGE } & -0.023 & $* * *$ & -0.021 & $* * *$ & -0.021 & $* * *$ & -0.023 & $* * *$ \\
\hline & $(0.002)$ & & $(0.002)$ & & $(0.002)$ & & $(0.002)$ & \\
\hline \multirow[t]{2}{*}{ GENDER } & 0.511 & $* * *$ & 0.514 & $* * *$ & 0.514 & $* * *$ & 0.514 & $* * *$ \\
\hline & $(0.034)$ & & $(0.034)$ & & $(0.034)$ & & $(0.034)$ & \\
\hline \multicolumn{9}{|l|}{ Region: } \\
\hline \multirow[t]{2}{*}{ REG2 } & - & & 0.637 & $* * *$ & 0.634 & $* * *$ & 0.770 & $* * *$ \\
\hline & & & $(0.084)$ & & $(0.084)$ & & $(0.083)$ & \\
\hline \multirow[t]{2}{*}{ REG3 } & - & & 0.660 & $* * *$ & 0.660 & $* * *$ & 0.697 & $* * *$ \\
\hline & & & $(0.078)$ & & $(0.078)$ & & $(0.078)$ & \\
\hline \multirow[t]{2}{*}{ REG4 } & - & & 0.466 & $* * *$ & 0.467 & $* * *$ & 0.507 & $* * *$ \\
\hline & & & $(0.085)$ & & $(0.085)$ & & $(0.085)$ & \\
\hline \multirow[t]{2}{*}{ REG5 } & - & & 0.292 & $* * *$ & 0.290 & $* * *$ & 0.402 & $* * *$ \\
\hline & & & $(0.092)$ & & $(0.092)$ & & $(0.092)$ & \\
\hline \multirow[t]{2}{*}{ Const } & -3.125 & $* * *$ & -3.601 & $* * *$ & -3.606 & $* * *$ & -3.099 & $* * *$ \\
\hline & $(0.116)$ & & $(0.134)$ & & $(0.133)$ & & $(0.126)$ & \\
\hline \multicolumn{9}{|l|}{ Panel B: Measures of fit } \\
\hline Log-Lik Full Model & -10315.6 & & -10259.7 & & -10259.8 & & -10334.8 & \\
\hline $\mathrm{LR}(\#)$ & 1361.8 & & 1473.6 & & 1473.4 & & 1323.43 & \\
\hline Prob $>$ LR & 0.000 & & 0.000 & & 0.000 & & 0.000 & \\
\hline
\end{tabular}




\begin{tabular}{lllll} 
McFadden's R2 & 0.061 & 0.066 & 0.067 & 0.060 \\
McKelvey and Zavoina's R2 & 0.106 & 0.120 & 0.120 & 0.110 \\
AIC & 1.090 & 1.084 & 1.084 & 1.092 \\
$\mathrm{n}$ & 18948 & 18948 & 18948 & 18948 \\
\hline \hline Sensitivity. Pr(+|CFCEXAM=1) & $12.69 \%$ & $12.69 \%$ & $12.65 \%$ & $9.21 \%$ \\
Specificity. Pr(- |CFCEXAM=0) & $97.60 \%$ & $97.49 \%$ & $97.52 \%$ & $98.04 \%$ \\
Positive predictive value. Pr(CFCEXAM=1|+) & $65.85 \%$ & $64.85 \%$ & $65.04 \%$ & $63.14 \%$ \\
Negative predictive value. Pr(CFCEXAM=0 |-) & $75.41 \%$ & $75.39 \%$ & $75.39 \%$ & $74.77 \%$ \\
Correctly classified & $74.92 \%$ & $74.84 \%$ & $74.85 \%$ & $74.31 \%$ \\
\hline \hline
\end{tabular}

IGC: General rating of all degrees offered by a higher education institution; CPC: Preliminary degree assessment; MAST: percentage of faculty holding a master's degree; ENADE: National Examination of student performance; AGE: candidate age; Gender: Male $(=1)$; Female $(=0)$; Region is a classificatory variable that classifies candidates according to the region where they completed the CFC exam. Note: Robust standard errors are in parentheses.

In Model 1, all variables except CPC are significant at the 1\% level. This means that the rating of a higher education institution (IGC) explains the CFC exam pass rate, consistent with evidence reported in other contexts (e.g., Grant et al., 2002; Morgan, 2015), and in accord with H1. As the IGC rating is calculated using the CPC ratings of all degrees offered by a HEI, the explanatory power seems to be concentrated in the IGC variable. This is the most important factor explaining pass rates in the CFC exam.

MAST is also a significant explanator of the CFC exam pass rate, corroborating $\mathrm{H} 3$. Furthermore, the higher the grade achieved in the ENADE exam, the more likely a candidate is to pass the CFC exam, corroborating H4. This accords with results reported by Colbert and Murray (1998), Eskey and Faley (1998), Grant et al. (2002), and Howell and Heshizer (2006). It confirms that past academic performance is related significantly to future performance.

The finding that younger candidates perform better accords with results reported by Santos (2012), Diaz (2017) and Roos (2009), mentioned earlier. Further, the correlation matrix in Table 4 and the fact that CPC and IGC average values decrease with age, suggests that older candidates were more likely to have studied in low-rated HEIs..

Regarding gender (H6), the independent variables do not permit us to conclude why males perform better. However, better performance by males is consistent with results reported by Santos (2012), Diaz (2007) and Bagamery et al. (2005).

In Model 2 we introduce the variable Region [REG]. Table 5 reveals the results are affected only slightly by doing so - the MAST variable reduces in significance from $1 \%$ to $5 \%$. The variable REG (Region) is significant at the 1\% level. Candidates from the Southeast, Northeast, South and Central-West are more likely to pass the exam than candidates from the North. This accords with results reported by Bugarim et al. (2014) that, for the 14 exams the CFC conducted prior to and including 2012, the regions with best performance were the South, Northeast and Southeast. GDP per capita in the Northeast is the lowest. But as shown in Table 2, the Northeast has HEIs with higher CPC and IGC scores than Regions 1 and 5.

In Model 3 we eliminated the CPC variable because of possible multicollinearity. The results are very similar. 
In Model 4 we eliminated the IGC to test H2. As can be seen, the hypothesis that the quality of a bachelor's degree in accounting is associated with CFC exam pass rates (H2) is corroborated. All the other results are similar.

Table 6 shows that Models 3 and 4 are not affected by multicollinearity. Collinearity statistics (VIF and Tolerance) were less than 4 and above 0.2, respectively. 
Table 6. Multicollinearity Results

\begin{tabular}{lcc}
\hline Variables & Tolerance & VIF \\
\hline IGC & 0.286 & 3.49 \\
CPC & 0.265 & 3.77 \\
MAST & 0.599 & 1.67 \\
ENADE & 0.735 & 1.36 \\
AGE & 0.965 & 1.04 \\
GENDER & 0.994 & 1.01 \\
REG & 0.943 & 1.06 \\
\hline
\end{tabular}

IGC: General rating of all degrees offered by a higher education institution; CPC: Preliminary degree assessment; MAST: percentage of faculty holding a master's degree; ENADE: National Examination of student performance; AGE: candidate age; Gender: Male $(=1)$; Female $(=0)$; REGION is a classificatory variable that classifies candidates according to the region where they completed the CFC exam.

Table 7 presents odds ratios and marginal effects for each logistic regression model. Odds ratios indicate the change in the probability of passing the CFC exam compared to the probability of failing, when there is a change of one unit in the independent variable. Marginal effects describe the change in the probability of passing the CFC exam when there is a change of one unit in the independent variable, while holding all other variables in the model constant. 
Table 7: Odds Ratios (OR) and Marginal Effects (ME) for Logit Regressions

\begin{tabular}{|c|c|c|c|c|c|c|c|c|}
\hline Model: & Model 1 & & Model 2 & & Model 3 & & Model 2 & \\
\hline & OR & $M E$ & OR & $M E$ & $O R$ & $M E$ & OR & $M P$ \\
\hline Variables rel & d to HEIs: & & & & & & & \\
\hline IGC & 2.152 & 0.139 & 2.101 & 0.134 & 2.138 & 0.137 & & \\
\hline & (0.128) & $(0.011)$ & $(0.128)$ & (0.011) & (0.093) & (0.008) & & \\
\hline СРС & $\begin{array}{c}1.022 \\
(0.052)\end{array}$ & $\begin{array}{c}0.004 \\
(0.009)\end{array}$ & $\begin{array}{c}1.022 \\
(0.053)\end{array}$ & $\begin{array}{c}0.004 \\
(0.009)\end{array}$ & - & - & $\begin{array}{c}1.597 \\
(0.059)\end{array}$ & $\begin{array}{c}0.085 \\
(0.007)\end{array}$ \\
\hline MAST & $\begin{array}{c}1.346 \\
(0.134)\end{array}$ & $\begin{array}{c}0.054 \\
(0.018)\end{array}$ & $\begin{array}{c}1.218 \\
(0.124)\end{array}$ & $\begin{array}{c}0.036 \\
(0.018)\end{array}$ & $\begin{array}{c}1.232 \\
(0.120)\end{array}$ & $\begin{array}{c}0.038 \\
(0.018)\end{array}$ & $\begin{array}{c}1.513 \\
(0.151)\end{array}$ & $\begin{array}{c}0.076 \\
(0.018)\end{array}$ \\
\hline Variables rel & $d$ to candid & & & & & & & \\
\hline ENADE & $\begin{array}{c}1.200 \\
(0.031)\end{array}$ & $\begin{array}{c}0.033 \\
(0.005)\end{array}$ & $\begin{array}{c}1.210 \\
(0.032)\end{array}$ & $\begin{array}{c}0.034 \\
(0.005)\end{array}$ & $\begin{array}{c}1.212 \\
(0.032)\end{array}$ & $\begin{array}{c}0.035 \\
(0.005)\end{array}$ & $\begin{array}{c}1.286 \\
(0.033)\end{array}$ & $\begin{array}{c}0.046 \\
(0.005)\end{array}$ \\
\hline AGE & $\begin{array}{c}0.978 \\
(0.002)\end{array}$ & $\begin{array}{c}-0.004 \\
(0.000)\end{array}$ & $\begin{array}{c}0.979 \\
(0.002)\end{array}$ & $\begin{array}{c}-0.004 \\
(0.000)\end{array}$ & $\begin{array}{c}0.979 \\
(0.002)\end{array}$ & $\begin{array}{c}-0.004 \\
(0.000)\end{array}$ & $\begin{array}{c}0.977 \\
(0.002)\end{array}$ & $\begin{array}{l}-0.004 \\
(0.000)\end{array}$ \\
\hline GENDER & $\begin{array}{c}1.667 \\
(0.057)\end{array}$ & $\begin{array}{c}0.093 \\
(0.006)\end{array}$ & $\begin{array}{c}1.672 \\
(0.058)\end{array}$ & $\begin{array}{c}0.093 \\
(0.006)\end{array}$ & $\begin{array}{c}1.673 \\
(0.058)\end{array}$ & $\begin{array}{c}0.093 \\
(0.006)\end{array}$ & $\begin{array}{c}1.672 \\
(0.057)\end{array}$ & $\begin{array}{c}0.094 \\
(0.006)\end{array}$ \\
\hline Region: & & & & & & & & \\
\hline REG2 & - & & $\begin{array}{c}1.890 \\
(0.159)\end{array}$ & $\begin{array}{c}0.105 \\
(0.013)\end{array}$ & $\begin{array}{c}1.885 \\
(0.159)\end{array}$ & $\begin{array}{c}0.105 \\
(0.013)\end{array}$ & $\begin{array}{c}2.160 \\
(0.180)\end{array}$ & $\begin{array}{c}0.129 \\
(0.013)\end{array}$ \\
\hline REG3 & - & & $\begin{array}{c}1.935 \\
(0.152)\end{array}$ & $\begin{array}{c}0.110 \\
(0.012)\end{array}$ & $\begin{array}{c}1.936 \\
(0.152)\end{array}$ & $\begin{array}{c}0.110 \\
(0.012)\end{array}$ & $\begin{array}{c}2.009 \\
(0.157)\end{array}$ & $\begin{array}{c}0.114 \\
(0.011)\end{array}$ \\
\hline REG4 & - & & $\begin{array}{c}1.593 \\
(0.135)\end{array}$ & $\begin{array}{c}0.074 \\
(0.013)\end{array}$ & $\begin{array}{c}1.595 \\
(0.135)\end{array}$ & $\begin{array}{c}0.074 \\
(0.013)\end{array}$ & $\begin{array}{c}1.660 \\
(0.140)\end{array}$ & $\begin{array}{c}0.079 \\
(0.012)\end{array}$ \\
\hline REG5 & - & & $\begin{array}{c}1.339 \\
(0.124)\end{array}$ & $\begin{array}{c}0.044 \\
(0.014)\end{array}$ & $\begin{array}{c}1.336 \\
(0.123)\end{array}$ & $\begin{array}{c}0.044 \\
(0.014)\end{array}$ & $\begin{array}{c}1.495 \\
(0.137)\end{array}$ & $\begin{array}{c}0.061 \\
(0.014)\end{array}$ \\
\hline Const & $\begin{array}{c}0.044 \\
(0.005)\end{array}$ & - & $\begin{array}{c}0.027 \\
(0.004)\end{array}$ & - & $\begin{array}{c}0.027 \\
(0.004)\end{array}$ & - & $\begin{array}{c}0.045 \\
(0.006)\end{array}$ & - \\
\hline
\end{tabular}

IGC: General rating of all degrees offered by a higher education institution; CPC: Preliminary degree assessment; MAST: percentage of faculty holding a master's degree; ENADE: National Examination of student performance; AGE: candidate age; Gender: Male $(=1)$; Female $(=0)$; Region is a classificatory variable that classifies candidates according to the region where they completed the CFC exam.

The odds ratio and marginal effects are consistent with previous results. When there is a change of one unit in IGC (for example, from 2 to 3), the probability of a candidate passing is 2.1 times higher than the probability of the candidate failing. The probability of passing the CFC exam increases about $14 \%$ when IGC increases from 2 to 3 . The probability of passing the CFC exam decreases $0.4 \%$ when age increases one year. The probability of a candidate from the Southeast and Northeast regions passing the CFC exam, compared to the probability of them failing, is almost two times higher than the probability for candidates from the North region. 
Although the Northeast is not a rich region in terms of GDP per capita, candidates in this region perform better than candidates in richer regions. This is explained by the generally higher quality of HEIs and degrees in the Northeast, as Table 2 reports. The higher performance of the Northeast region (and of its HEIs) seems to be related to the strong tradition of commercial education in this region. Schools of commerce were established from the beginning of the nineteenth century in the region (in Bahia, Pernambuco and Maranhão) to support the sugar industry (see Araújo \& Rodrigues 2013). They were among the first such schools to be established in Brazil (Araújo et al., 2016).

\section{Conclusions}

We have assessed whether previously reported factors associated with professional entry exam performance in other countries can be generalized. This exploration of factors influencing pass rates in the CFC's professional entry exam in Brazil should be particularly useful for the MEC, professional accountants, and the CFC. This study helps to understand factors influencing pass rates, and devise ways to enhance the supply (and likely performance) of future professional accountants.

We conclude that the quality of HEIs, the percentage of faculty holding a master's degree, the score of students in ENADE, age, gender, and region of Brazil where a student completed the exam, are important factors explaining CFC exam pass rates. The most important factor is the quality of HEIs. The findings support views (expressed by [then] CFC President Coelho (1999) and by Iudícibus and Marion (1986), Martins (2000), and Andere and Araújo (2008)) that the proliferation of lowly rated HEIs offering bachelor degrees in accounting has reduced the quality of accounting education in Brazil. In 2012, the pass rate in the CFC's professional entry exam compared unfavorably with the pass rates achieved by candidates in exams conducted by leading international professional accounting bodies. The results point strongly to a relationship between a low pass rate in the CFC exam and two factors: first, a low score for the quality of a higher education institution (IGC); and second, a low score for student ability (ENADE).

The results should attract the attention of the MEC and invigorate efforts to identify poor quality degree programs in accounting that are offered by HEIs in Brazil. Such programs are implicated strongly in the under supply of suitably qualified accountants in Brazil. The reduced number of $\mathrm{PhDs}$ and master's degrees in accounting is also a general concern of accounting scholars and professionals (Bugarim et al., 2014).

The ENADE result is particularly important too, since it reinforces the CFC's concerns about the proliferation of HEIs offering poor quality degrees. In some low rated institutions, professores horistas (teachers contracted for a designated number of hours of teaching only) are engaged to teach accounting (but do not engage in research). Such employment practices decrease the quality of teaching and research.

The effect of age and gender on CFC exam pass rates deserves further exploration. Why do females perform worse than males, especially in a context where females are the majority of candidates? The finding that younger candidates perform better than older candidates (H5) can be explained as follows. The CFC exam is an academic exam, not a practice-oriented exam. Hence, the more familiar a candidate is with this type of exam, the better. The work experience that comes with age is often not related to the main topics of accounting addressed in the CFC exam. Another explanation is that older students often work and study at the same time. In this regard, Santos (2012) found that married students perform worse than single students. 
Rodrigues, Santos, Santana and Lemes (2016) concluded that in all editions of the ENADE exam, female students had statistically significantly worse results than male students. This result is consistent with those of Andrade (2005), Silva et al. (2010) and Santos (2012). There are claims that the poorer results reported for females in the CFC exam and in ENADE are related to the fact that "women are still the main person responsible for household tasks and for taking care of children and other relatives, which means a double burden for those who also perform economic activities” (Bruschini, 2007, p. 542). Such responsibilities are claimed to hinder female productive activity "since taking care of children is the activity that is most time consuming in the household tasks for women" (Bruschini, 2007, p.542). Thus, we argue that this gender inequality may account for the poorer performance of females than males in the CFC exam. Thus, the poorer performance of female candidates in the CFC exam and ENADE seems to be related to social inequality between women and men. Important policy issues regarding matters of gender equity and child-care would seem to deserve closer consideration by bureaucrats, policy makers and opinion leaders within the accounting profession.

Additionally, initiatives to encourage increased pass rates by older candidates should be encouraged. The CFC should advise HEIs to promote CFC review programs in the classroom so that older candidates can re-connect with academic-type examining and be schooled in contemporary accounting issues.

Regional effects are also important in explaining the CFC exam pass rate. The probability that a candidate from the Southeast region will pass the CFC exam is almost two times greater than for a candidate from the North - one of the poorest regions of Brazil. Government should seek to improve educational resources in poorer regions such as the North. Although the Northeast is the poorest region in terms of GDP per capita, the CFC exam performance of students from this region was better than for students from richer regions, such as Central-West and North. Despite contention that there is an association between economic and social well-being and CFC exam pass rate, the level of development of accounting education in a region seems likely to be explained, in good part, by historical reasons, such a prior levels of investment in in accounting education.

This study is cross-sectional. The results should be read with caution. When the CFC makes exam results available over a longer time period, it would be opportune then to study the determinants of exam performance using panel data. Because we were restricted to secondary data, the number of variables available for selection was limited. This could be remedied if the CFC required candidates to provide more socio-economic data to enable other pertinent variables to be explored (e.g., the conduct of a CFC review program in the classroom, or the average delay after graduation before taking the CFC exam). In this study we used ENADE to evaluate students' performance. Another variable that could be used in future research is ENEM (Exame Nacional do Ensino Médio), which is used for admission to higher education in Brazilian public universities. Our data do not permit a definitive explanation of why older, and female candidates perform worse. These matters should be analyzed in detail in future research. Additionally, since there are differences within regions, it would be instructive to determine the pass rates between states and cities in each region. Furthermore, since most studies of professional entry exam performance in accounting have been undertaken in the USA, it would be important to add findings from other settings, such as Australia, China or Portugal.

\section{Funding}


This work was supported financially by the research unit on Governance, Competitiveness and Public Policy (project POCI-01-0145-FEDER-006939), through funds provided by COMPETE2020 - Programa Operacional Competitividade e Internacionalização (POCI); and Fundação para a Ciência e a Tecnologia.

\section{REFERENCES}

Allen, A., \& Woodland, A. M. (2006). The 150-hour requirement and the number of CPA exam candidates, pass rates, and the number passing. Issues in Accounting Education, 21(3), 173-193.

Allen, A., \& Woodland, A. M. (2012). Response to: The ongoing debate about the impact of the 150-hour education requirement on the supply of Certified Public Accountants. Issues in Accounting Education, 27(4), 1045-1057.

Andere, M. A., \& Araújo, A. M. P. D. (2008). Aspectos da formação do professor de ensino superior de Ciências Contábeis: uma análise dos programas de pós-graduação. Revista de Contabilidade e Finanças, 19(48), 91-102.

Araújo, W. G., \& Rodrigues, L. L. (2013). As primeiras Aulas do Comércio do Brasil no Século XIX. Paper presented at the XIV Congresso Internacional de Contabilidade e Auditoria, Lisbon. Available at http://www.otoc.pt/news/comcontabaudit/pdf/81.pdf, accessed 5 July 2015.

Araújo, W. G., Rodrigues, L. L., \& R. Craig. (2016). “"Empire as an Imagination of the Centre": The Rio de Janeiro School of Commerce and the Development of Accounting Education in Brazil', forthcoming Critical Perspectives on Accounting.

Ashbaugh, D. L., \& Thompson, A. F. (1993). Factors distinguishing exceptional performance on the uniform CPA exam. Journal of Education for Business, 68(6), 334-342.

Bagamery, B. D., Lasik, J. J, \& Nixon, D.R. (2005). Determinants for success on the ETS business major field exam for students in an undergraduate multisite regional university business program. Journal of Education for Business, 81(1), 55-63.

Barilla, A. G., Jackson, R. E. \& Mooney, J. L. (2008). The CPA exam as a post-curriculum accreditation assessment. Journal of Education for Business, 83(5), 270-274.

Barreyro, G. B. (2008). De exames, rankings e mídia. Avaliação 13(3), 863-868.

Bittencourt, H. R., Casartelli, A.O., \& Rodrigues, A. C. M. (2009). Sobre o índice geral de cursos (ICG). Avaliação, 14(3), 667-682.

Blanden, J., Gregg, P. \& Macmillan, L. (2007). Accounting for intergenerational income persistence: non cognitive skills, ability and education. Economic Journal, 117, 43-60.

Bline, D. M., Perreault, S. \& Zheng, X. (2015). Do accounting faculty characteristics impact CPA exam performance? An investigation of nearly 700,000 Examinations. Issues in Accounting Education, 31(3), 291-300.

Boone, J., Legoria, J., Seifert D. L, \& Stammerjohan W. W. (2006). The associations among accounting program attributes, 150-hour status, and CPA exam pass rates. Journal of Accounting Education, 24, 202-215. 
Briggs, G. P., \& He, L. (2012). The 150 credit-hour requirement and CPA examination pass rates - A four year study. Accounting Education: An International Journal, 21 (1), 97108.

Brito, M. R. F. (2008). O SINAES e o ENADE: da concepção à implantação. Avaliação, 13(3), 841-850.

Bruschini, M. C. A. (2007). Work and gender in Brazil in the last ten years. Cadernos de Pesquisa, 37(132), 537-572.

Bugarim, M. C. C., Rodrigues, L.L., Pinho J.C., \& Machado, D. (2014). O desempenho dos profissionais de contabilidade no exame de suficiência do cfc: uma análise de conglomerados regionais. Revista de Contabilidade e Organizações, 8(22), 60-71.

Castanheira, A. M. P., Masson, T. J., \& Miranda, L. F. (2010). Impacto dos indicadores gerados a partir do ENADE na avaliação dos cursos de engenharia. In XXXVIII Congresso Brasileiro de Educação em Engenharia, Fortaleza, CE.

Coelho, J. M. A. (1999). Exame de suficiência: um passo adiante. Revista Brasileira de Contabilidade, 28(117), 17-19.

Colbert, G. \& Murray, D. (1998). The association between states' education requirements and CPA exam performance. Research in Accounting Regulation, 12, 93-108.

Davidson, R. A. (2002). Relationship of study approach and exam performance. Journal of Accounting Education, 20, 29-44.

Diaz, M. D. M. (2007). Efetividade no ensino superior brasileiro: aplicação de modelos multinível à análise dos resultados do Exame Nacional de Cursos. Revista EconomiA, 8(1), 93-120.

Dunn, W. M., \& Hall, T. W. (1984). An empirical analysis of the relationships between CPA examination candidate attributes and candidate performance. Accounting Review, 674689.

Eskew, R. K. and Faley, R.H. (1988). Some determinants of students performance in the first college-level financial accounting course. Accounting Review, 63(1), 137-147.

Fernandes, R., Pazello, E. TLeitão, T. M. S. P., \& Moriconi, G. M. (2009). Avaliação de cursos na educação superior: a função e a mecânica do conceito preliminar de curso. Brasília, DF: MEC, INEP.

Freitas, S. C. D. (2016). The Impact of Evaluation Use on Accounting Programs' Performance: An Exploratory Study. Revista de Administração Contemporânea, 20(6), 733-752.

Gramling, L. J., \& Rosman, A. J. (2009). The ongoing debate about the impact of the 150hour education requirement on the supply of certified public accountants. Issues in Accounting Education, 24 (4), 465-479.

Gramling, L. J., \& Rosman, A J. (2013). The ongoing debate of and direction for future research about the impact of the 150-hour education requirement on the supply of Certified Public Accountants. Issues in Accounting Education, 28(3), 503-512. 
Grant, C. T., Ciccotello, C. S., \& Dickie, M. (2002). Barriers to professional entry: How effective is the 150-hour rule? Journal of Accounting and Public Policy, 21, 71-93.

Gujarati, D.N. (1995). Basic Econometrics. New York: McGraw-Hill.

Haen J., Spielbauer-Vandenberg, A., Bloniarzm, A. \& Diestler, A. (2014). The relationship between 150-credit hours, accounting credit hours and CPA pass rates. Journal of Finance and Accountancy, 16, 1-12.

Hahn, W., \& Fairchild, C. (2015). Usefulness of the uniform Certified Public Accounting examination for assessment of learning and program quality determination at US institutions of higher learning. Journal of Accounting and Finance, 15(5), 95.

Howell, C., \& Heshizer, B. (2008). Characteristics that assist future public accountants pass the CPA exam on fewer attempts. Journal of Applied Business and Economics, 8(3), 57-66.

Howell C., \& Heshizer, B. (2006). AACSB accreditation and success on the uniform CPA exam. Journal of Applied Business and Economics, 6(3), 9-17.

INEP. (Instituto Nacional de Estudos e Pesquisas Educacionais Anísio Teixeira) - (2008). Sinopse Estatística da Educação Superior Graduação. Disponível em www.inep.gov.br.

Iudícibus, S., \& Marion, J. C. (1986). As faculdades de ciências contábeis e a formação do contador. Revista Brasileira de Contabilidade, 15(56), 50-56.

Madeira, G. J., Mendonça, K. F. C., \& Abreu, S. M. 2003. A disciplina teoria da Contabilidade nos exames de suficiência e provão. Contabilidade Vista \& Revista 14 (ed. Especial): 103-122.

Marchelli, P. S. (2007). O sistema de avaliação externa dos padrões de qualidade da educação superior no Brasil: considerações sobre os indicadores. Estudos em Avaliação Educacional, 18 (37), 189-216.

Martins, C. B. (2000). O ensino superior brasileiro nos anos 90. São Paulo em Perspectiva, 14(1), 41-60.

Marts, J. R., Baker, J. D., \& Garris, J. M. (1988). Success on the CPA examination in AACSB accredited and non-accredited schools. Accounting Educators' Journal, 1, 7491.

Matos, R. (2017). O Brasil dividido e a rede urbana fracionada. Cadernos do LESTE, 1, 286341.

MEC. (2012). Sinopse da educação superior. Available online http://portal.inep.gov.br/superior-censosuperior-sinopse. Accessed on 22 May 2014.

Miller, G. J., \& Nouri, H. (2015). An examination of the relationship between obtaining AACSB accounting accreditation and certified public accountant (CPA) exam pass rates. International Journal of Economics and Accounting, 6(2), 179-194.

Morgan, J. (2015). The relationship of CPA exam delay after graduation to institutional CPA exam pass rates. Journal of Finance and Accountancy, 18, 1-11. 
Morgan, J., Bergin, J. \& Sallee, L. (2012). Three Types of Business School Accreditation and their Relationships to CPA Exam Scores of Graduates, Advances in Business Research, 3(1), 25-35.

Neto, J. D. (2010). O retorno do exame de suficiência do CFC. Revista de Contabilidade do Mestrado em Ciências Contábeis da UERJ, 14 (1), 1-18.

Nix, P. E., \& Nix, D. E. (1988). Differences in certified public accounting exam pass-fail rates among colleges and universities. Journal of Education for Business, 64(3), 101105.

Nossa, V. (1999a). A necessidade de professores qualificados e atualizados para o ensino da Contabilidade. In Congresso Brasileiro de Custos. São Paulo, SP.

Nossa, V. (1999b). Formação do corpo docente dos cursos de graduação em Contabilidade no Brasil: uma análise crítica. Caderno de Estudos da FIPECAFI, 21, 1-20.

Nouri, H., \& Miller, G. J. (2015). An examination of pass rates for candidates without advanced degrees on the computerized Certified Public Accountant (CPA) exam: association to Advance Collegiate Schools of Business (AACSB)- accredited vs. unaccredited institutions. Global Perspectives on Accounting Education, 12, 135-147.

Peixoto, M. C. L. (2011). Avaliação institucional externa no SINAES: considerações sobre a prática recente. Avaliação, 16(1), 11-36.

Peleias, I., Silva, G., Segreti, J., and Chiorotto, A. (2007), "Evolução do Ensino da Contabilidade no Brasil: Uma Análise Histórica”, Revista Contabilidade \& Finanças, 18, 19-32.

Pereira, C. J. (2012). O ENADE como indicador de qualidade é uma farsa. Revista Científica UNIRB, 3(4), 111-115.

Raghunandan, K., Read, W. J., \& Brown, C. D. (2003). The 150-hour rule: does it improve CPA exam performance? Managerial Auditing Journal, 18(1), 31-38.

Reis, J. B. M. (2016). A Nova Matriz Econômica e a recessão econômica do governo Dilma Rousseff: Erros e consequências sobre o nível de atividade econômica. In VIII Congreso de Relaciones Internacionales (La Plata, 2016).

Rodrigues, D. S., Santos, N. D. A., Santana, M. D. S., \& Lemes, A. P. M. Diferenças entre Gênero, Etnia e Perfil Socioeconômico no Exame Nacional de Desempenho do Estudante do Curso de Ciências Contábeis. XIII Congresso USP, Building knowledge in Accounting, São Paulo.

Ristoff, D., \& Giolo, J. (2006). O Sinaes como sistema. Revista Brasileira de PósGraduação, 3(6), 193-213.

Rodrigues, L. L., Schmidt, P., Santos, J., \& Fonseca, P. (2011). A research note on accounting in Brazil in the context of political, economic and social transformations, 1860 - 1964. Accounting History, 16(1), 111-123.

Rodrigues, L.L., Schmidt, P., Santos, J., Fonseca, P. (2012). The origins of modern accounting in Brazil: Influences leading to the adoption of IFRS. Research in Accounting Regulation, 24, 15-24. 
Roos, S. (2009). Factors affecting Southern African students' success in CIMA examinations. Meditari Accountancy Research, 17(1), 48-67.

Santos, N. D. A. (2012). Determinantes do desempenho acadêmico dos alunos dos cursos de ciências contábeis (Doctoral dissertation, Universidade de São Paulo).

Santos, N.D.A, \& Afonso, L. E. (2016). Análise do Conteúdo das Provas da Área de Ciências Contábeis: Edições do Provão 2002/2003 e do Enade de 2006. Avaliação: Revista da Avaliação da Educação Superior, 21(2).

Schwartzman, S. (2008). O “conceito preliminar” e as boas práticas de avaliação do ensino superior. Estudos Revista da Associação Brasileira de Mantenedoras de Ensino Superior, 38, 9-32.

Segall, M., Gollhardt, L. \& Morrell, J. S. 2007. The information systems analyst national assessment exam: factors of success. Information Systems Education Journal, 5(40), 312.

Silva, M. C. R. , Vendramini, C. M. M. \& Lopes, F. L. (2010). Diferenças entre Gênero e Perfil Sócio-Econômico no Exame Nacional de Desempenho do Estudante. Avaliação, 15(3), 185-202.

Titard, P. L. \& Russell, K. A. (1989). Factors affecting CPA examination success. Accounting Horizons, 3, 53-59.

Verhine, R. E., Dantas, L. M. V., \& Soares, J.F. (2006). Do Provão ao ENADE: uma análise comparativa dos exames nacionais utilizados no Ensino Superior Brasileiro. Ensaio: Avaliação de Políticas Públicas em Educação, 14 (52), 291-310.

Vasconcelos, N. V. C. D. (2010). Análise do sistema de avaliação da educação superior brasileira. In X Coloquio Internacional sobre Gestión Universitaria em América del Sur, Mar del Plata, Argentina. 


\begin{abstract}
Notes
${ }^{1}$ Such as by Eskew and Faley (1988), Nix and Nix (1988), Ashbaugh and Thompson (1993), Davidson (2002), Grant, Ciccotello, and Dickie (2002), Raghunandan, Read, and Brown (2003), Bagamery, Lasik, and Nixon (2005), Allen and Woodland (2006), Boone, Legoria, Seifert, and Stammerjohan (2006), Segall, Gollhardt, and Morrell (2007), Barilla, Jackson, and Mooney (2008), Briggs and He (2012), Morgan, Bergin, and Sallee (2012), Gramling and Rosman (2013), Haen, Spielbauer-Vandenberg, Bloniarz, and Diestler (2014), Morgan (2015), Miller and Nouri (2015), Nouri and Miller (2015).

2 MEC (2006). Conselho Escolar e o financiamento da educação no Brasil, available on line at: http://portal.mec.gov.br/seb/arquivos/pdf/Consescol/cad\%207.pdf, accessed in March 2017.

${ }^{3}$ The lato sensu graduate programs include specialization programs such as MBA (Master of Business Administration) and are practice-oriented.

${ }^{4}$ Other than for medicine where the last year is the sixth.

${ }^{5}$ An average mark is obtained using a weighting of $25 \%$ for the general exam and $75 \%$ for the disciplinespecific component.

${ }^{6}$ This is evidence of the legalist character of Brazilian accounting, noted by Rodrigues et al. (2011).

${ }^{7}$ The University of S. Paulo has had a leading role in accounting education. The first research unit in accounting was also created at this university in 1946 (Peleias et al., 2006; Rodrigues et al., 2012). This pioneer role of the University of S. Paulo can still be observed today.

${ }^{8}$ Other ways of measuring the ability of individual candidates or groups of candidates include college entrance exam scores and grades (Grant et al., 2002; Colbert \& Murray 1998). These data are not available in Brazil.

${ }_{9}^{9}$ IBGE, Contas Regionais do Brasil 2013: Produto Interno Bruto, população residente e Produto Interno Bruto per capita, segundo as Grandes Regiões $e$ as Unidades da Federação, http://saladeimprensa.ibge.gov.br/noticias?view=noticia\&id=1\&busca=1\&idnoticia=3038, $\quad$ accessed 19 November 2015.

${ }^{10}$ Use of the percentage score the candidate earned on the exam did not yield better results.

${ }^{11}$ We also tested the variable DMAST, a dummy variable assigned a value of 0 if the percentage of faculty holding a master's degree in accounting was $<50 \%$, and 1 otherwise. The results of the model were significant but the variable was not significant.

${ }^{12}$ We decided to provide information related to region*age and region*gender using only text, and not by providing additional tables. But tables are available upon request.
\end{abstract}

